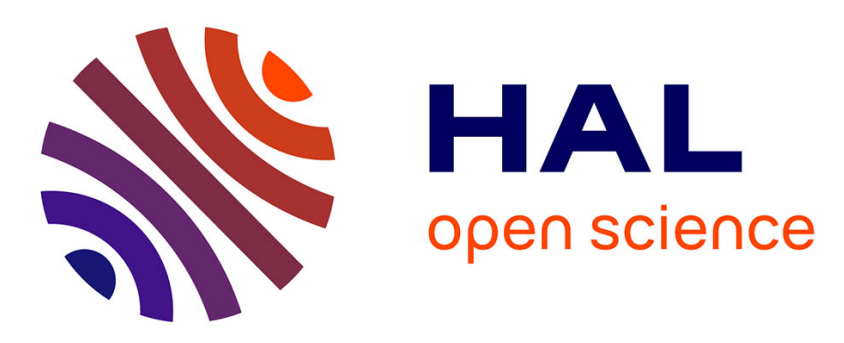

\title{
Novel single-ion conducting electrolytes based on polyvinylidene fluoride polymer for Lithium metal batteries
}

Thi Khanh Ly Nguyen, Gérald Lopez, Cristina Iojoiu, Renaud Bouchet, Bruno Ameduri

\section{To cite this version:}

Thi Khanh Ly Nguyen, Gérald Lopez, Cristina Iojoiu, Renaud Bouchet, Bruno Ameduri. Novel singleion conducting electrolytes based on polyvinylidene fluoride polymer for Lithium metal batteries. Journal of Power Sources, 2021, 498, pp.229920. 10.1016/j.jpowsour.2021.229920 . hal-03214440

\author{
HAL Id: hal-03214440 \\ https://hal.science/hal-03214440
}

Submitted on 1 May 2021

HAL is a multi-disciplinary open access archive for the deposit and dissemination of scientific research documents, whether they are published or not. The documents may come from teaching and research institutions in France or abroad, or from public or private research centers.
L'archive ouverte pluridisciplinaire $\mathbf{H A L}$, est destinée au dépôt et à la diffusion de documents scientifiques de niveau recherche, publiés ou non, émanant des établissements d'enseignement et de recherche français ou étrangers, des laboratoires publics ou privés. 


\title{
Novel single-ion conducting electrolytes based on polyvinylidene fluoride polymer for Lithium metal batteries
}

\author{
Thi Khanh Ly, Nguyen, ${ }^{a}$ Gérald, Lopez, ${ }^{b}$ Cristina, Iojoiu,,${ }^{a, c, ~}$ Renaud, \\ Bouchet ${ }^{a, \#,}$ Bruno, Ameduri ${ }^{b, \#}$ \\ ${ }^{a}$ Univ. Grenoble Alpes, Univ. Savoie Mont Blanc, CNRS, Grenoble INP, LEPMI, 38000 Grenoble, \\ France, \\ ${ }^{\mathrm{b}}$ Institut Charles Gerhardt, Université de Montpellier, CNRS, ENSCM, Montpellier, France \\ ${ }^{c}$ Réseau sur le Stockage Electrochimique de l'Energie (RS2E), CNRS, FR3459, 80039 Amiens Cedex, \\ France \\ \# bruno.ameduri@enscm.fr (B. Ameduri), renaud.bouchet@lepmi.grenoble-inp.fr (R. Bouchet), \\ cristina.iojoiu@ @ lepmi.grenoble-inp.fr (C. Iojoiu)
}

\section{Highlights}

- $\quad$ SIPE based on PVDF was successfully prepared with possible scalability.

- Good conductivity, high $\mathrm{Li}^{+}$transport number and excellent interfacial stability $v s$. Lithium were obtained.

- $\quad$ SIPE used as both electrolyte and cathode binder for high voltage LMP based battery demonstrated promising cell performance.

\begin{abstract}
A single-ion polymer electrolyte (SIPE) based on PVDF-based random copolymer (LiPVDF) was synthesized in water from the radical copolymerization of vinylidene fluoride (VDF) with perfluoro -2-methyl-3-oxa-5-sulfonimido[-3-oxa-5-sulfonyl fluoride] vinyl ether (VEPFSIS) initiated by potassium persulfate. The purified polymer, characterized by ${ }^{1} \mathrm{H}$ and ${ }^{19}$ F NMR spectroscopy, ICP-MS, and size-exclusion chromatography, contains 96 mol\% VDF with an average molar mass of $128 \mathrm{~kg} \mathrm{~mol}^{-1}$. The Li-PVDF was cast into self-standing membranes and then swollen with a 50/50 v/v mixture of ethylene carbonate and propylene carbonate. The membrane was analyzed using DSC, TGA, pulse field gradient (PFG)-NMR and electrochemical methods. The solvent-doped membrane exhibited a lithium ion transport number close to 1 with lithium ion conductivities higher than $10^{-4} \mathrm{~S} \mathrm{~cm}^{-1}$ at $30{ }^{\circ} \mathrm{C}$, an electrochemical stability up to $4.3 \mathrm{~V} v s . \mathrm{Li}^{+} / \mathrm{Li}$ and an excellent reversibility upon continuous lithium plating/striping cycles. In addition, prototype Li/NMC battery cells using Li-PVDF as
\end{abstract}


both electrolyte and cathode binder in the NMC based composite cathode showed reversible cycling and good performance at $60{ }^{\circ} \mathrm{C}$. The results demonstrated the promising potential of this new single-ion polymer family in intrinsically safe all solid-state lithium metal based batteries.

Keywords: Lithium metal; PVDF; polymer electrolyte; single-ion; NMC composite electrode.

\section{Introduction}

Nowadays, due to the increasing environmental issues in our modern society, the transition from traditional fossil fuel to renewable energy sources in combination with an electrified transport has become a necessity, but it requires more efficient energy storage and conversion technologies [1]. Lithium metal-based batteries (LMBs) are foreseen as the next battery technology beyond lithium-ion thanks especially to the lithium high theoretical specific capacity (3.8 $\left.\mathrm{Ah} \mathrm{g}^{-1}\right)$ and low redox potential (-3.04 V vs. SHE) [2-4] compared to currently used graphite or graphite/silicon based negative electrodes [5]. However, the practical use of Lithium metal remains limited especially by severe safety issues due to irregular lithium plating during the charging using liquid electrolytes [6], an issue for which polymer based electrolytes [7,8], poly(ionic liquid) [9] or organic/inorganic composite electrolytes [10-12] seem to be a promising alternative $[13,14]$.

Among the studied polymer-based systems, besides the most common used polyethylene oxide (POE) [15], poly(vinylidene fluoride) (PVDF) and its derivatives are also attractive thanks to their mechanical stability upon a broad temperature window up to $160{ }^{\circ} \mathrm{C}$, and their high chemical and electrochemical stability (up to $4.5 \mathrm{~V} v s . \mathrm{Li}^{+} / \mathrm{Li}$ ) [16-18]. Indeed, PVDF is a well-known binder of both negative and positive composite electrodes for Li-ion technology. However, PVDF and its derivatives are not able to insure a good ionic conductivity of the Li cation in a dried state due their low ability for solvation [19]. In addition, the high degree of crystallinity of PVDF based polymers, which provides a high mechanical resistance, reduces the effective ionic conductivity, limiting the amount of amorphous paths for ion transport [20]. Nevertheless, they can be plasticized using polar solvents such as carbonates, and therefore are largely studied as gel electrolytes [21]. The polymer membranes based on VDF [16,22-25], copolymers [26-31] or blends with other polymers [32-38], gelled with a liquid electrolyte made from carbonate solvents and lithium salt, exhibit a high conductivity of up to $10^{-3} \mathrm{~S} \mathrm{~cm}^{-1}$ at $30{ }^{\circ} \mathrm{C}$ and a good electrochemical stability of up to $4.5 \mathrm{~V} v s . \mathrm{Li}^{+} / \mathrm{Li}[38,39]$. However, the conductivity of these gels is mainly driven by the carbonate solvation of both cation and anion, 
which leads to lithium transference number $\left(t_{L i}^{+}\right)$lower than 0.45 [40]. This induces the formation of ionic concentration gradients when the cell is under current, limiting the maximal power and leading to nucleation and growth of lithium dendrites during the recharge (lithium plating) [41,42]. To avoid these issues, single-ion conducting polymer structures (SIPE) i.e., polymers in which the anion is covalently bounded to the immobile macromolecular backbone, leading to only one mobile ion, the $\mathrm{Li}^{+}$ion, were designed to suppress the formation of a gradient of ion concentration under current, and by consequence prevent lithium dendrite nucleation and growth [43-47].

Among all SIPEs, those based on PVDF have not been widely reported due to the difficulty of synthesis. Up to now, most of the SIPEs were synthesized by covalently grafting the lateral ionic chain onto the VDF backbone by irradiation [48] or reaction with amines [49]. For example, by ${ }^{60} \mathrm{Co} \gamma$-ray irradiation, Ding et al. [48] successfully synthesized new PVDF based SIPE by grafting hexafluorobutyl methacrylate (HFMA) and 2-acrylamido-2methylpropanesulfonic acid (AMPS) onto the PVDF backbone. Polymer electrolytes prepared from sulfonated PVDF soaked in EC/DMC (v/v = 1/1) presented a conductivity of $2.08 \times 10^{-5} \mathrm{~S}$ $\mathrm{cm}^{-1}$ at $30{ }^{\circ} \mathrm{C}$ combined with a $\mathrm{Li}^{+}$transference number of 0.93 . This SIPE was used as a binder for preparing $\mathrm{LiFePO}_{4}$ cathode, allowing a better cycling compared to the PVDF binder alone. Generally, $\mathrm{LiFePO}_{4} / \mathrm{Li}$ cell with sulfonated PVDF SIPE as both binder and electrolyte provides stable charge/discharge cycling with a capacity of $142 \mathrm{mAh} \mathrm{g}^{-1}$ at $0.1 \mathrm{C}$ at room temperature [48]. On the other hand, lithium sulfonate-grafted PVDF-HFP polymer was successfully synthesized by direct grafting of taurine onto PVDF backbone and was used as binder for $\mathrm{LiFePO}_{4}$ cathode [49]. The use of grafted SIPE allows a better solid electrolyte interface and faster charge transfer, resulting in better battery performance and higher capacity retention compared to cathode with PVDF binder. However, these methods of synthesis cannot be easily scaled up due to either the use of radioactive source, or the difficulty to control the amount and position of grafted anions onto the PVDF backbone.

Recently, Ameduri et al. have developed a new method of synthesis of SIPE based on PVDF from the radical copolymerization of VDF and a functional monomer, which allows them to control both composition and structure of the single-ion copolymers [50]. These SIPEs were studied in proton exchange membrane fuel cells. Herein, based on such synthetic methodology, a new kind of SIPE promising for lithium batteries has been synthesized by radical copolymerization of VDF with a perfluoroalkylsulfonimide vinyl ether lithium sulfonate and fully characterized by means of NMR spectroscopy and size exclusion chromatography. The membrane cast from this new copolymer has been soaked, for different 
times, in an ethylene/propylene carbonates mixture (50/50 in vol.). The transport (conductivity and transference number) and thermodynamic properties of the resulting membranes have been thoroughly studied. The best composition has been used for the assembly of Li/SIPE/Li symmetrical cells to check its ability to reversibly plat and strip lithium metal. Their electrochemical window has also been analyzed. Finally, composite cathode electrode based on lamellar $\mathrm{LiNi}_{0.33} \mathrm{Mn}_{0.33} \mathrm{Co}_{0.33} \mathrm{O}_{2}$ (NMC 111) as active material and SIPE as both co-binder and electrolyte were formulated and cycled in coin cells (Li/SIPE/composite cathode) at $60{ }^{\circ} \mathrm{C}$.

\section{Experimental section}

\subsection{Materials}

Dimethylformamide (DMF) and potassium persulfate were purchased from Aldrich and used as received. Vinylidene fluoride (VDF) and perfluoro -2-methyl-3-oxa-5-sulfonimido[-3-oxa5-sulfonyl fluoride] vinyl ether (VEPFSIS) were kindly provided by Arkema (France) and Juhua (China) companies, respectively.

\subsection{Li-PVDF synthesis}

The PVDF based SIP was synthesized in water by following the same protocol as described in a previous work [50] by radical copolymerization of two monomers, vinylidene fluoride (VDF) and VEPFSIS, in presence of potassium persulfate as the initiator (KPS) (Scheme 1). The VEPFSIS introduces two anions, i.e., sulfonimide and sulfonate anions (VEPFSIS-Li), the last one being obtained by the hydrolysis of fluorosulfonic function in presence of $\mathrm{LiOH}$ [51,52]. 


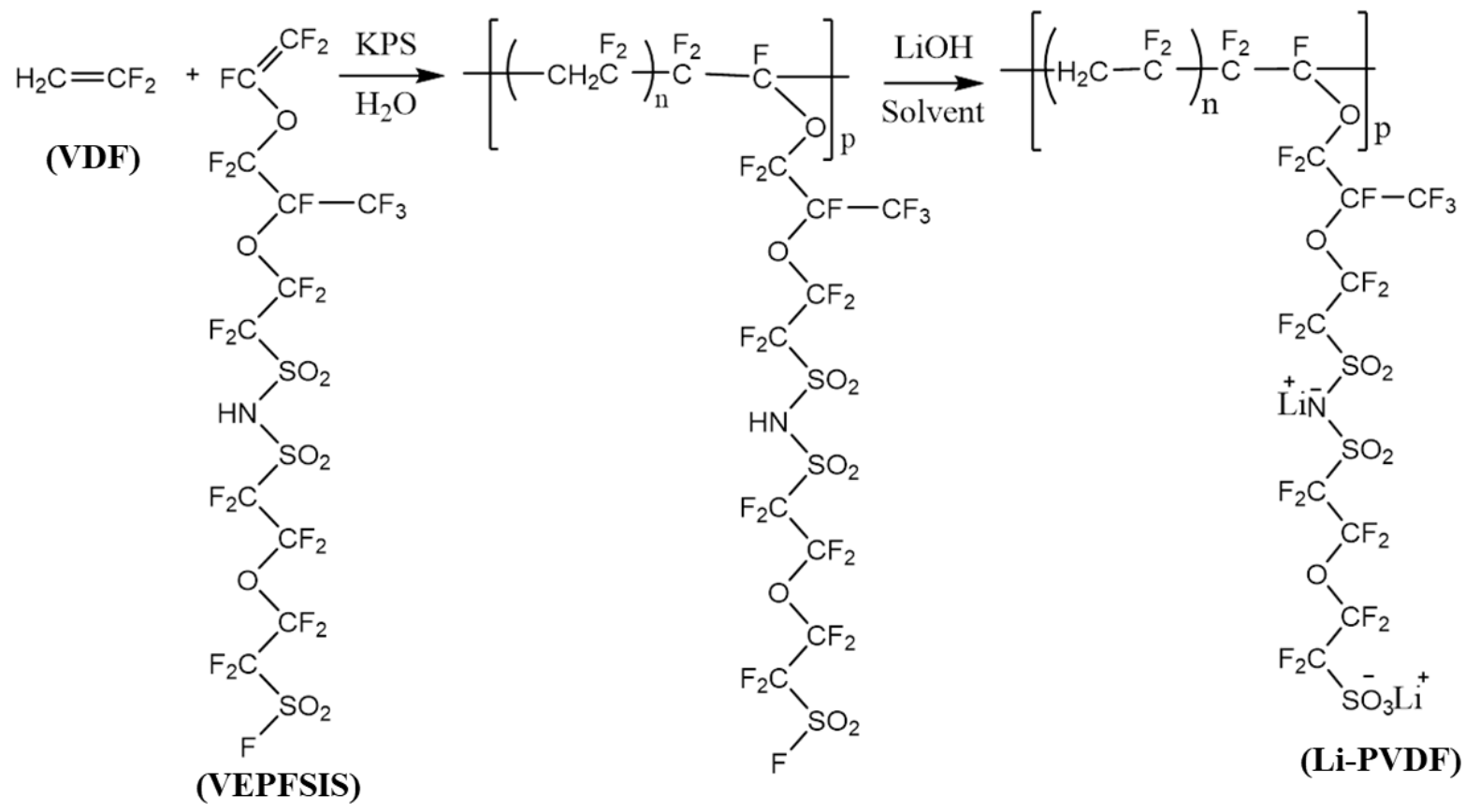

Scheme 1. Radical copolymerization of vinylidene fluoride (VDF) and VEPFSIS, and modification of $\mathrm{SO}_{2} \mathrm{~F}$ into $\mathrm{SO}_{3} \mathrm{Li}$ with the formation of single-ion conducting copolymer, LiPVDF.

In a typical synthesis, Li-PVDF was prepared in a $100 \mathrm{~mL}$ Hastelloy Parr autoclave equipped with a bourdon pressure gauge, a rupture disk and inlet and outlet valves. First, the autoclave was purged with 30 bars of nitrogen pressure to prevent any leakage. Then, a $20 \mathrm{~mm} \mathrm{Hg}$ vacuum was operated for $15 \mathrm{~min}$. The reactants including potassium persulfate (KPS) as initiator (36 mg, $0.04 \mathrm{~mol} \%$ ), perfluorinated vinyl ether monomer bearing both a sulfonyl fluoride and sulfonimide (VEPFSIS) (15.41 g, $6 \mathrm{~mol} \%)$ and water $(55 \mathrm{~mL})$ as solvent were inserted into the autoclave through a funnel tightly connected to the vessel. After cooling, VDF (20 g, 94 mol\%) was transferred by double weighing (i.e., the difference of weight before and after transferring VDF) into the autoclave. The reactor was gradually heated up to $70{ }^{\circ} \mathrm{C}$ and the pressure in the autoclave reached a maximum of 85 bars. The reaction was stopped after $16 \mathrm{~h}$ and showed a good VDF conversion since the pressure went down to 14 bars $(\Delta \mathrm{P}=$ 71 bars). Then, the autoclave was cooled down to room temperature using an ice bath and the unreacted VDF was vented off. After opening the autoclave, the resulting total product mixture was dissolved in DMF, then precipitated from cold water. The copolymer (15.48 g, 1eq.) was then suspended in a water-methanol mixture $(300 \mathrm{~mL}, 1 / 1, \mathrm{v} / \mathrm{v})$ and $\mathrm{LiOH}(0.65 \mathrm{~g}, 1 \mathrm{eq}$.$) was$ added to modify the $\mathrm{SO}_{2} \mathrm{~F}$ into $\mathrm{SO}_{3} \mathrm{Li}[51,52]$. The reaction mixture was stirred for $48 \mathrm{~h}$ at 
room temperature. Li-PVDF (copolymer poly(VDF-VEPFSIS-Li)) in form of white powder was recovered by filtration then dried under high vacuum at $80{ }^{\circ} \mathrm{C}$ until constant weight. In order to remove any trace of non-reacted VEPFSIS or inorganic salts such as $\mathrm{LiOH}, \mathrm{LiF}$, the polymer was immersed in a large excess of deionized water under stirring for $2 \mathrm{~h}$ and then filtered. This operation was repeated several times until the $\mathrm{pH}$ of washing water was 7 . To ensure the non-reacted VEPFSIS was totally removed, the purified copolymer was characterized by 19F NMR spectroscopy and the absence of signal at $-134 \mathrm{ppm}$ (assigned to $\mathrm{CFO}$ in $\mathrm{F} 2 \mathrm{C}=\mathrm{CFO}$ - of this monomer) is a good evidence. After filtration, the polymer was dried under vacuum (10-3 mbars) at $80{ }^{\circ} \mathrm{C}$ until constant weight to produce $12.4 \mathrm{~g}$ of copolymer as a white solid powder (80 wt.\% yield)

\section{Preparation of single ion conducting polymer electrolyte (SIPE)}

In a typical protocol, the Li-PVDF membrane was cast from a solution of $10 \mathrm{wt} \% \mathrm{Li}-\mathrm{PVDF}$ in DMF. The solution was prepared at room temperature, filtered over a $0.45 \mu \mathrm{m}$ filter, degassed under vacuum and cast in a Petri dish, then the solvent was evaporated at $60{ }^{\circ} \mathrm{C}$ for 2 days. The resulting membrane was further immersed during $24 \mathrm{~h}$ in water in order to eliminate the residual DMF. Then, the washed membrane was dried at $80{ }^{\circ} \mathrm{C}$ under vacuum for $24 \mathrm{~h}$. The dried membranes were stored in an argon filled glovebox (Jacomex, $\mathrm{O}_{2}, \mathrm{H}_{2} \mathrm{O}<1 \mathrm{ppm}$ ) for at least one week before use.

Solvent uptake was conducted in glove box using a mixture of 50/50 by volume of ethylene carbonate/propylene carbonate (EC/PC). The solvent mixture was previously dried with $3 \AA$ molecular sieves until the water content was lower than 5 ppm (by Karl Fisher) before used. Samples were weighed before and after soaking in solvent after different immersion times. Before each weight measurement, the excess solvent on the membrane surface was removed using a Kimtech paper. Swelling tests were conducted three times and error bars come from the standard deviation of the measures. The results are presented in Fig. 1.

For the purpose of clarity, these membranes are denoted Li-PVDF-x in which $\mathrm{x}$ is the weight per cent of solvent calculated from the following equation:

$$
x(\%)=\frac{m_{\mathrm{EC} / \mathrm{PC}}}{m_{\mathrm{EC} / \mathrm{PC}}+m_{L i-P V D F}} \times 100 \%
$$

where $\mathrm{m}_{\mathrm{EC} / \mathrm{PC}}$ and $\mathrm{m}_{\mathrm{Li}-\mathrm{PVDF}}$ are the weights of solvent and Li-PVDF membrane, respectively. 


\subsection{Characterization}

NMR analysis was conducted with a Bruker AVANCE III HD spectrometer at frequencies of 400.15 MHz for ${ }^{1} \mathrm{H}$ and $376.52 \mathrm{MHz}$ for ${ }^{19} \mathrm{~F}$. Data treatment was performed on the software MestRe-C 2.3a.

Thermogravimetric analysis (TGA) was carried out from 25 to $600{ }^{\circ} \mathrm{C}$ at a heating rate of 10 ${ }^{\circ} \mathrm{C} \min ^{-1}$ under a nitrogen flow of $50 \mathrm{~mL} \cdot \mathrm{min}^{-1}$ using a thermogravimetric analyzer (TGA, 1 STARe System from Mettler-Toledo).

The molecular weight was measured by size exclusion chromatography (WATERS 515 HPLC) coupled with multi-angle light laser scattering Wyatt Dawn EOS detector (SECMALLs-) using a 10 AGILENT 2xPLgel-Mixed-D as column and DMF (Alfa Aesar - HPLC grade $99.7 \%)$ with $\mathrm{NaNO}_{3}(0.1 \mathrm{M})$ as solvent. A solution of around $1 \mathrm{wt} \%$ of polymer was injected through the polypropylene filter of $0.45 \mu \mathrm{m}$ under solvent flow rate of $1 \mathrm{~mL} \mathrm{~min}{ }^{-1}$. Received data from refractometer and MALLS (Fig. S3) were analyzed by using ASTRA software provided by Wyatt.

\section{ICP-MS}

Inductively coupled plasma mass spectrometry (ICP-MS) was carried out on a Perkin Elmer Nexion 2000c device. Lithium concentration of Li-PVDF membrane was determined using standard solutions of $0,2,5,10,20$ and $50 \mathrm{ppb}$ relative to an invariable quantity of internal standard (2.5 ppb of Rh). Li-PVDF polymer was degraded in extra pure acid nitric and diluted with ultrapure water in order to obtain a concentration in the calibration range. The obtained data are processed using Syngistix software.

Self-diffusion coefficients of lithium and fluorine were assessed by pulse field gradient (PFG)-NMR using a 9.4T Bruker Avance 400 with a diffusion probe of $5 \mathrm{~mm}$. The magnitude of the pulsed field gradient was varied from $0 \leq \mathrm{g} \leq 1000 \mathrm{G} \mathrm{cm}^{-1} ; \Delta$ was set at $200 \mathrm{~ms}$ and $\delta$ was set between $1 \mathrm{~ms}$ and $5 \mathrm{~ms}$, depending on the diffusion coefficient of the mobile species. SIPEs containing $50 \mathrm{wt} \% \mathrm{EC} / \mathrm{PC}$ were cut in bands and introduced into an NMR tube (diameter $4 \mathrm{~mm}$ ) hermetically sealed inside the glovebox. The measurements were carried out at $70.0 \pm 0.5^{\circ} \mathrm{C}$.

The $\mathrm{Li}^{+}$transference number of polymer electrolyte can be determined either by PFG-NMR or electrochemical methods. In the former method, the $\mathrm{Li}^{+}$transport number $\left(\mathrm{t}_{\mathrm{NMR}}{ }^{+}\right)$can be 
calculated using the diffusion coefficients measured by NMR of the $\mathrm{Li}$ and the anion (Fluorine) following Eq. 2:

$$
t_{N M R}^{+}=\frac{\mathrm{D}_{\mathrm{Li}}}{\mathrm{D}_{\mathrm{Li}}+\mathrm{D}_{\mathrm{F}}}
$$

By the second method, $\mathrm{t}_{\text {electrochem. }}^{+}$can also be estimated using a coupling technique of DC polarization with chronoamperometric (CA) measurement, and Electrochemical Impedance Spectroscopy on $\mathrm{Li} / \mathrm{Li}$ symmetric cells. The experiment has been carried out on VMP300 potentiostat (Biologic). The $\mathrm{Li}^{+}$transport number was then calculated from Watanabe [53] (Eq. 3) approaches:

$$
\mathrm{t}_{\text {electrochem. }}^{+}=\frac{\mathrm{R}_{\mathrm{b}}}{\left(\frac{\Delta \mathrm{V}}{\mathrm{I}_{\mathrm{s}}}-\mathrm{R}_{\mathrm{s}}\right)}
$$

in which $\Delta \mathrm{V}$ is the static voltage of the cell, $\mathrm{I}_{\mathrm{S}}$ is the current obtained at the steady state, $\mathrm{R}_{\mathrm{b}}$ is the bulk electrolyte resistance, and $R_{s}$ the steady-state resistance of the lithium electrode/electrolyte interface. The advantage of the Watanabe's approach [53] compared to the classical Bruce and Vincent's [54], is to use directly the measured electrolyte resistance by EIS instead of calculating it thanks to the initial current value after imposing the voltage which strongly depends on the response time of the potentiostat used.

Differential scanning calorimetry (DSC) was performed on a 1 STARe System from Mettler-Toledo under nitrogen flow $\left(50 \mathrm{ml} \mathrm{min}^{-1}\right)$ and a heating rate of $10{ }^{\circ} \mathrm{C} \mathrm{min}{ }^{-1}$. Each sample was evaluated through two heating and one cooling cycles from $-100{ }^{\circ} \mathrm{C}$ to $180{ }^{\circ} \mathrm{C}$ for dry samples and from $-150{ }^{\circ} \mathrm{C}$ to $180{ }^{\circ} \mathrm{C}$ for the plasticized samples. The $\mathrm{T}_{\mathrm{g}}$ values were assessed from the mid-point in the heat flow jump, while the melting points were determined from the onset temperature of the melting peak. The crystallinity degree $(\chi)$ of Li-PVDF can be calculated by applying Eq. 4 :

$$
\chi=\frac{\Delta \mathrm{H}_{\mathrm{m}}}{\Delta \mathrm{H}_{o}} \times 100 \%
$$

where $\Delta H_{o}\left(104.5 \mathrm{~J} \mathrm{~g}^{-1}\right)$ corresponds to the melting enthalpy of a $100 \%$ crystalline PVDF $[55,56]$ and $\Delta H_{m}$ is the melting enthalpy of the copolymer (determined by DSC in $\mathrm{J} \mathrm{g}^{-1}$ ), respectively.

Concerning plasticized samples, the enthalpy and degree of crystallinity were calculated by subtracting the weight of the EC/PC solvent uptake. 
Ionic conductivity of the Li-PVDF membranes was determined by electrochemical impedance spectroscopy using an impedance analyzer (Hewlett Packard 4192A) with an excitation voltage amplitude of $20 \mathrm{mV}$ in the frequency range from $5 \mathrm{~Hz}$ to $13 \mathrm{MHz}$. The temperature range probed was from 0 to $80 \pm 0,1{ }^{\circ} \mathrm{C}$ thanks to a climatic chamber (Vötsch VC4018). Data were recorded every $10^{\circ} \mathrm{C}$ after a stabilization time of $1 \mathrm{~h}$ minimum. Dry and plasticized membranes were sandwiched between two stainless steel blocking electrodes and sealed in Swagelok ${ }^{\circledR}$-type cells inside the glovebox before measurement. Same measurement was conducted twice for the same amount of contained solvent and the average values with 5\% error were presented in Fig. 2. The conductivity was calculated from the following equation:

$$
\sigma=\frac{L}{R \times S}
$$

where L, S and R stand for the electrolyte membrane thickness, the electrode surface area and the bulk membrane resistance (determined from Zview fitting the Nyquist's plot, e.g. Fig. S7), respectively.

The conductivity data were fitted using the Vogel-Tammann-Fulcher equation [57-59]:

$$
\sigma=\frac{A}{\sqrt{T}} \exp \left(\frac{-\mathrm{E}_{\mathrm{a}}}{\mathrm{R}\left(\mathrm{T}-\mathrm{T}_{0}\right)}\right)
$$

where $\sigma$ is the ionic conductivity $\left(\mathrm{S} \mathrm{cm}^{-1}\right)$, the pre-exponential term $\mathrm{A}$ is a constant proportional to the amount of ionic mobile charges, $\mathrm{E}_{\mathrm{a}}$ is a pseudo-activation energy $\left(\mathrm{J} \mathrm{mol}^{-1}\right)$, $\mathrm{R}$ is the perfect gas constant $\left(8.314 \mathrm{~J} \mathrm{~mol}^{-1} \mathrm{~K}^{-1}\right)$ and $\mathrm{T}_{\mathrm{o}}=\mathrm{T}_{\mathrm{g}}-50$ is the ideal glass transition temperature.

Electrochemical stability of the electrolyte membranes was determined using cyclic voltammetry $(\mathrm{CV})$ carried out in a coin cell prepared by sandwiching the electrolyte membranes between a lithium disk and a blocking stainless steel electrode. Measurements were conducted on a VMP3 potentiostat (BioLogic) using a slow sweep rate of $0.1 \mathrm{mV} \mathrm{s}^{-1}$ in a voltage ranging from -0.5 to $+5 \mathrm{~V}$ vs. $\mathrm{Li}^{+} / \mathrm{Li}$. In addition, the lithium plating and stripping coulombic efficiency was calculated from the area ratio of the lithium plating peak area over the lithium stripping peak area obtained around $0 \mathrm{~V} v s . \mathrm{Li}^{+} / \mathrm{Li}$.

Evaluation in symmetric Li/Li. Lithium stripping/plating experiments were performed by sandwiching the electrolyte membranes between two lithium disks $(\varnothing=12 \mathrm{~mm})$, assembled in coin cells, and applying selected current densities from \pm 0.02 to $\pm 0.4 \mathrm{~mA} \mathrm{~cm}^{-2}$ for $30 \mathrm{~min}$ per interval (with 5 min rest between each step) using a VMP3 potentiostat (BioLogic). 
Battery performance. Battery cycling was performed in prototype coin cells using a lithium foil as the anode and standard lamellar $\mathrm{LiNi}_{0.33} \mathrm{Mn}_{0.33} \mathrm{Co}_{0.33} \mathrm{O}_{2}$ (NMC 111) as the cathode material. The NMC composite cathode was prepared by solution casting onto an aluminum foil of a well-dispersed slurry mixture of $60 \mathrm{wt} \% \mathrm{NMC}, 10 \mathrm{wt} \%$ carbon black (C65) and 30 $\mathrm{wt} \%$ of polymer binder, i.e., $25 \mathrm{wt} \% \mathrm{Li}-\mathrm{PVDF}$ and $5 \mathrm{wt} \%$ PVDF in NMP. After NMP evaporation at $60{ }^{\circ} \mathrm{C}$ for $24 \mathrm{~h}$, the cathode was pressed at $120{ }^{\circ} \mathrm{C}$ to reduce the porosity $(\leq 10 \%)$ before being swollen in EC-PC to reach a similar SIPE composition to the electrolyte membrane. The areal capacity of the prepared electrode is $0.33-0.36 \mathrm{mAh} \mathrm{cm}^{-2}$ giving a theoretical accessible capacity at $4.2 \mathrm{~V}$ vs. $\mathrm{Li}^{+} / \mathrm{Li}$ for NMC 111 of $160 \mathrm{mAh} \mathrm{g}^{-1}$ [60]. Charge and discharge tests were performed at $60{ }^{\circ} \mathrm{C}$ using the galvanostatic cycling with potential limitation (GCPL) technique in a VMP3 potentiostat from Biologic over a voltage range from 2.8 to $4.2 \mathrm{~V}$.

\section{Results and discussion}

\subsection{Characterization of Li-PVDF single-ion conducting polymer}

The purity of the polymer was verified by ${ }^{1} \mathrm{H}$ and ${ }^{19} \mathrm{~F}$ NMR spectroscopy and the composition of the final copolymer was calculated from ${ }^{19}$ F-NMR spectra (Fig. S1) using the peak area ratio between the signals corresponding to the side chain and those assigned to PVDF segments (Eq. 7). The peaks appearing between -78 and $-82 \mathrm{ppm}$ are attributed to the 11 fluorine atoms of VEPFSIS-Li, while those centered at $-92,-110,-113$ and $-116 \mathrm{ppm}$ are characteristic of VDF units [50]. The calculated ratios are gathered in Table 1. As expected from perfluorovinyl ethers, it is observed that the reactivity of the ionic monomer is lower than that of VDF monomer and its incorporation in the copolymer structure is lower than that in the initial ratio. From the resulting composition, we calculated the $\mathrm{Li}$ content (mequivLi/g copolymer) from Eq. 8 considering that each side chain contains two Li cations, i.e., one $\mathrm{Li}$ perfluorosulfonate and one perfluorosulfonimide (Table 1).

$$
\begin{gathered}
\text { VEPFSIS-Li/VDF ratio by }{ }^{19} \mathrm{~F} \text { NMR }=\frac{\int_{-77}^{-83} \mathrm{I} / 11}{\left(\int_{-91}^{-96} \mathrm{I}+\int_{-109}^{-110} \mathrm{I}+\int_{-103}^{-115} \mathrm{I}+\int_{-116.5}^{-117} \mathrm{I}\right) / 2} \\
\mathrm{n}(\mathrm{Li}) / \mathrm{g}_{\text {copolymer }}=\frac{n_{V E P F S I S-L i} \times \text { number of Li per chain }}{m_{L i-P V D F}}=\frac{\left(100 \%-w t \%_{P V d F}\right) * 2}{\mathrm{M}_{\text {VEPFSIS-Li }}}
\end{gathered}
$$

where $\mathrm{M}_{\mathrm{VEPFSIS-Li}}$ and $\mathrm{M}_{\mathrm{VDF}}$ worth $815 \mathrm{~g} \mathrm{~mol}^{-1}$ and $64 \mathrm{~g} \mathrm{~mol}^{-1}$, respectively. 
The chemical composition of the synthesized SIPE was also determined by thermogravimetric analysis (Fig. S2). The polymer weight loss taking place at around $320-350{ }^{\circ} \mathrm{C}$ was associated to the degradation of lateral side chains according to Colpaert et al. (i.e., only sulfonate and sulfonimide side chain PFSIS-Li) [50]. By assuming that this decomposition is complete, the chemical composition, i.e., the weight fraction of PVDF segment in Li-PVDF, can be estimated using Eq. 9:

$$
\text { wt } \% \text { PVDF by TGA }=100 \%-\text { wt } \% \text { VEPFSIS-Li }=100 \%-\frac{w t{ }_{P F S I S L i} * \mathrm{M}_{\text {VEPFSIS-Li }}}{\mathrm{M}_{\mathrm{PFSISLi}}}
$$

where $\mathrm{M}_{\text {PFSISLi }}=734 \mathrm{~g} \mathrm{~mol}^{-1}$.

The obtained results (Table 1) are in good agreement with those deduced from ${ }^{19} \mathrm{~F}$ NMR spectroscopy, confirming the chemical composition of the synthesized SIP. The lithium content values calculated from NMR, TGA and ICP are very close (Table 1), which proves the high purity of ionic polymer.

The molar mass was determined thanks to size exclusion chromatography and was calculated from both laser diffusion and refractometer signal (Fig. S3). The obtained results (Table 1) show a high $\mathrm{M}_{\mathrm{n}}$ of $128 \mathrm{~kg} \mathrm{~mol}^{-1}$ and a dispersity (PDI) of 3, which is expected for a conventional radical copolymerization.

Table 1. Chemical compositions, IECs and molar mass of Li-PVDF powder.

\begin{tabular}{|c|c|c|c|c|c|c|c|c|c|c|c|c|c|}
\hline \multirow[t]{2}{*}{ SIP } & \multicolumn{2}{|c|}{$\begin{array}{c}\text { Ratio } \\
\text { VDF/PFVESIS }\end{array}$} & \multicolumn{3}{|c|}{ wt $\%$ PVDF $(\%)$} & \multicolumn{5}{|c|}{$\begin{array}{l}\text { Li concentration } \\
\quad\left(\text { mequiv } \mathrm{g}^{-1}\right)\end{array}$} & \multicolumn{3}{|c|}{$\begin{array}{l}\text { Molar mass } \\
\left(\mathrm{kg} \mathrm{mol}^{-1}\right)\end{array}$} \\
\hline & Theory & ${ }^{19} \mathrm{~F}$ NMR & Theory & ${ }^{19} \mathrm{~F}$ NMR & TGA & Theory & ${ }^{19} \mathrm{~F}$ NMR & TGA & ICP & Average $^{a}$ & $\mathrm{M}_{\mathrm{n}}$ & $\mathrm{M}_{\mathrm{w}}$ & $\mathrm{PDI}=\mathrm{M}_{\mathrm{w}} / \mathrm{M}_{\mathrm{n}}$ \\
\hline Li-PVDF & $94: 6$ & $96: 4$ & 55 & 66 & 65 & 1.09 & 0.83 & 0.86 & 0.82 & $0.84 \pm 0.02$ & 128 & 390 & 3.1 \\
\hline
\end{tabular}

${ }^{\mathrm{a}}$ Average value from three experimental methods ${ }^{19} \mathrm{NMR}$, TGA and ICP.

\subsection{Fabrication and characterization of SIPE membrane}

The thermodynamic behavior of Li-PVDF analyzed by DSC (Table 2) shows two transition temperatures: the first one is around $110{ }^{\circ} \mathrm{C}$, possibly attributed to specific relaxation temperature to PVDF copolymers, i.e., the mid-temperature transition [61] while the second one, corresponding to the PVDF melting peak, appears at around $155^{\circ} \mathrm{C}$ [62]. The melting of the PVDF crystalline phase in the Li-PVDF copolymer takes place at least $10{ }^{\circ} \mathrm{C}$ lower than 
that of the pure PVDF, which suggests that the copolymer forms crystallites with smaller size [63]. The melting temperature has to be also affected by the presence of ca. 4 mol.\% of bulky comonomer. This behavior is in agreement with a random copolymer structure $[17,18]$. From the data in Table 2, the crystallinity degree of Li-PVDF is around $26.5 \%$, being at least 1.5 times lower than that of a membrane cast from standard pure high molar mass PVDF $(\Delta \mathrm{H}>$ 40-50 $\mathrm{J} \mathrm{g}^{-1}, \chi_{\mathrm{c}}=38-48 \%$ ) [62]. This phenomenon is due to the presence of side chains, which affects the crystallization of PVDF sequences, similarly to the case of poly(VDF-co-HFP) copolymers [26].

The conductivity of Li-PVDF was measured in the $50-80{ }^{\circ} \mathrm{C}$ temperature range. Due to its high $\mathrm{T}_{\mathrm{g}}$, Li-PVDF copolymer can only reach $10^{-6} \mathrm{~S} \mathrm{~cm}^{-1}$ at $80^{\circ} \mathrm{C}$, which is not satisfactory for battery applications. In order to dissociate the ion pairs and to increase the Li mobility, LiPVDF membranes were plasticized with a mixture of two high boiling and flash point carbonates [64], i.e., 50/50 v/v EC/PC. The plasticization of PVDF by carbonate solvents is rather interesting for lithium-battery application $[65,66]$ due to their high dielectric constant and electrochemical stability. The solvent uptake (eq. 1) as a function of soaking time of the Li-PVDF membranes is illustrated in Fig. 1.

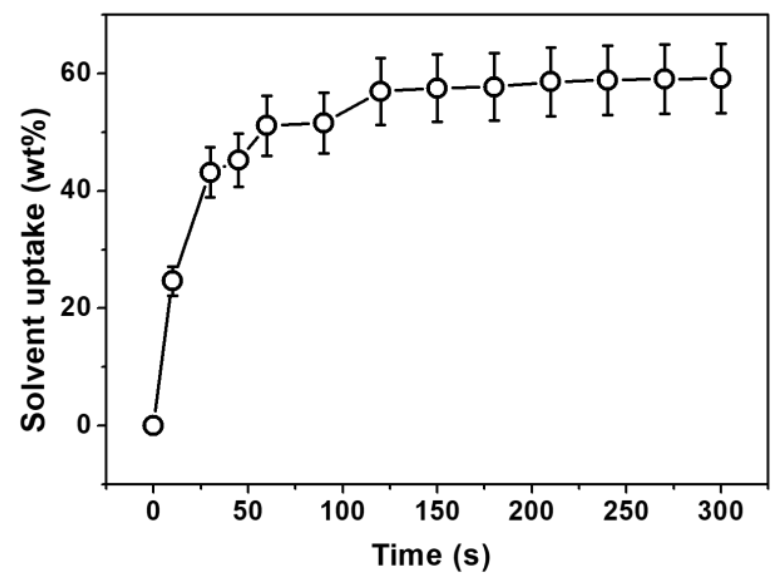

Fig. 1. Solvent uptake versus soaking time of Li-PVDF.

SIPE membrane reached an equilibrium after only $100 \mathrm{~s}$, which confirms the strong affinity of the matrix with the carbonate solvent with an uptake of $58 \pm 6 \mathrm{wt} \%$, slightly higher than the PVDF swelling ratio in solvent mixture such as EC/DEC or EC/DMC [67], due to the existence of ionic fraction and a lower crystallinity. The membrane containing $60 \%$ is solid and mechanically stable easy to handle, as shown in Fig. S4.

Lithium concentration (in mequiv/g) in plasticized Li-PVDF membranes (Table 2) can then be recalculated using the following equation: 


$$
\mathrm{n}(\mathrm{Li}) / \mathrm{g}_{\mathrm{SIPE}}=\frac{n(L i)}{m_{L i-P V D F}+m_{E C-P C}}=0.84 \times(1-x(\%) / 100)
$$

where 0.84 is the concentration in pure Li-PVDF and $\mathrm{x}(\%)$ is the weight per cent of solvent in plasticized membrane. The increase of the solvent amount in the membrane induces a continuous decrease of the glass transition temperature $\left(\mathrm{T}_{\mathrm{g}}\right)$ (Table 2), owing to the increase of the molecular dynamics of polymer segments swollen by the solvent [68]. After the incorporation of the solvent (up to $40 \mathrm{wt} \%$ ) into Li-PVDF, SIPE displays slightly increased crystallinity and decreased melting point compared to the solvent-free membranes. This can be explained by solvent induced PVDF crystallization due to increase of molecular dynamics, which facilitates polymer chains reorganization [16] into crystallites. Indeed, this phenomenon has been already reported, i.e. an increase in polymer crystallinity by soaking it in a liquidphase solvent, e.g. in the case of poly(ethylene terephthalate) [69]. However, their crystallite sizes become smaller with the increase of the solvent content because the melting point significantly decreased [70]. Above $40 \mathrm{wt} \%$ of solvent uptake, the presence of a second endothermic peak around $0{ }^{\circ} \mathrm{C}$ is observed by DSC analysis (Fig. S5). This second peak grows with the solvent content and may correspond to the crystallization of solvent rich domains, which are in poor interaction with the polymer, although the melting enthalpy and temperature of PVDF domains continue to decrease.

Table 2. Glass transition temperature $\left(\mathrm{T}_{\mathrm{g}}\right)$, melting temperatures $\left(\mathrm{T}_{\mathrm{m}}\right)$ and melting enthalpies $\left(\Delta \mathrm{H}_{\mathrm{m}}\right)$ of pure and plasticized Li-PVDF membranes as a function of the solvent content.

\begin{tabular}{|c|c|c|c|c|c|c|c|c|c|c|}
\hline $\begin{array}{l}\text { Solvent } \\
\text { uptake } \\
\text { (wt \%) }\end{array}$ & $\begin{array}{c}\mathrm{Li} \\
\text { (mequiv }^{-1} \text { ) }\end{array}$ & $\begin{array}{c}\mathrm{T}_{\mathrm{g}} \\
\left({ }^{\circ} \mathrm{C}\right)\end{array}$ & $\begin{array}{c}\mathrm{T}_{\mathrm{mLi-PVDF}} \\
\left({ }^{\circ} \mathrm{C}\right)\end{array}$ & $\begin{array}{c}\Delta \mathrm{H}_{\mathrm{m}} \\
\left(\mathrm{J} \mathrm{g}^{-1}\right)\end{array}$ & $\begin{array}{c}\Delta \mathrm{H}_{\mathrm{m}} \\
\left(\mathrm{J} \mathrm{g}^{-1} \mathrm{SIPE}\right)\end{array}$ & $\begin{array}{c}\Delta \mathrm{H}_{\mathrm{mPVDF}} \mathrm{b} \\
\left(\mathrm{J} \mathrm{g}^{-1} \mathrm{PVDF}\right)\end{array}$ & $\begin{array}{c}\chi_{\mathrm{c} \text { PVDF }} \\
(\%)\end{array}$ & $\begin{array}{c}\mathrm{T}_{\mathrm{m} \text { EC-PC }} \\
\left({ }^{\circ} \mathrm{C}\right)\end{array}$ & $\begin{array}{c}\Delta \mathrm{H}_{\mathrm{EC}-\mathrm{PC}}{ }^{\mathrm{c}} \\
\left(\mathrm{J} \mathrm{g}^{-1}\right)\end{array}$ & $\begin{array}{l}\chi_{\mathrm{CEC}^{\mathrm{d}}} \\
(\%)\end{array}$ \\
\hline 0 & 0.84 & -- & 159 & $18 \pm 2$ & $18 \pm 2$ & $28 \pm 3$ & 26.5 & -- & -- & \\
\hline 15 & 0.71 & -50 & 135 & $18 \pm 2$ & $22 \pm 2$ & $34 \pm 3$ & 32.2 & -- & -- & \\
\hline 20 & 0.66 & -65 & 124 & $17 \pm 2$ & $21 \pm 2$ & $31 \pm 3$ & 30.0 & -- & -- & \\
\hline 33 & 0.56 & -73 & 119 & $13 \pm 2$ & $19 \pm 2$ & $29 \pm 3$ & 27.8 & -- & -- & \\
\hline 44 & 0.46 & -80 & 103 & $5 \pm 1$ & $9 \pm 1$ & $14 \pm 1$ & 13.2 & 4 & $23 \pm 3$ & 28.1 \\
\hline 55 & 0.37 & -97 & 99 & $3 \pm 1$ & $6 \pm 1$ & $8 \pm 1$ & 7.9 & -4 & $34 \pm 3$ & 42.6 \\
\hline 60 & 0.33 & -99 & 96 & $2 \pm 1$ & $4 \pm 1$ & $7 \pm 1$ & 6.3 & -5 & $36 \pm 3$ & 44.6 \\
\hline
\end{tabular}

${ }^{\mathrm{b}, \mathrm{c}} \Delta \mathrm{H}$ recalculated as a function of PVDF content in the membrane (Eq. 4).

${ }^{\mathrm{d}} \Delta \mathrm{H}_{\mathrm{EC}}=13.5 \mathrm{~kJ} \mathrm{~mol}^{-1}\left(=153.4 \mathrm{~J} \mathrm{~g}^{-1}\right.$ from reference [71]).

\subsection{Ionic transport properties}

The diffusion coefficient of lithium $\left(\mathrm{D}_{\mathrm{Li}}\right)$ in Li-PVDF-55 membrane at $70{ }^{\circ} \mathrm{C}$, measured by PFG-NMR spectroscopy, was found to be $8 \times 10^{-11} \mathrm{~m}^{2} \mathrm{~s}^{-1}$, while fluorine $\left(D_{\mathrm{F}}\right)$ was not measurable, which demonstrates that the $\mathrm{Li}^{+}$transport number is, as expected, close to 1 [46]. This value was also measured at $60^{\circ} \mathrm{C}$ by an electrochemical method using the Watanabe 
approach [53] based on a potentiostatic polarization of lithium symmetric cell (the time dependent current response and the impedance obtained in steady state are shown in Fig. S6). Lithium transport number was calculated to be $0.87 \pm 0.3$, which is comparable to other single-ion conducting systems reported in the literature $[43,72,73]$ and in agreement with the results obtained from PFG-NMR results.

The ionic conductivities of Li-PVDF-x as a function of temperature for different solvent uptakes are plotted in Arrhenius coordinates in Fig. 2a. Generally, for all solvent contents, the data display a thermally activated conductivity with a characteristic curvature of VTF model assigned to the increase of free volume induced from the expansion of the polymer [33]. Interestingly, there is no drop of conductivity at high temperature, which means that the carbonates display sufficient affinity with the Li-PVDF matrix to avoid any evaporation.
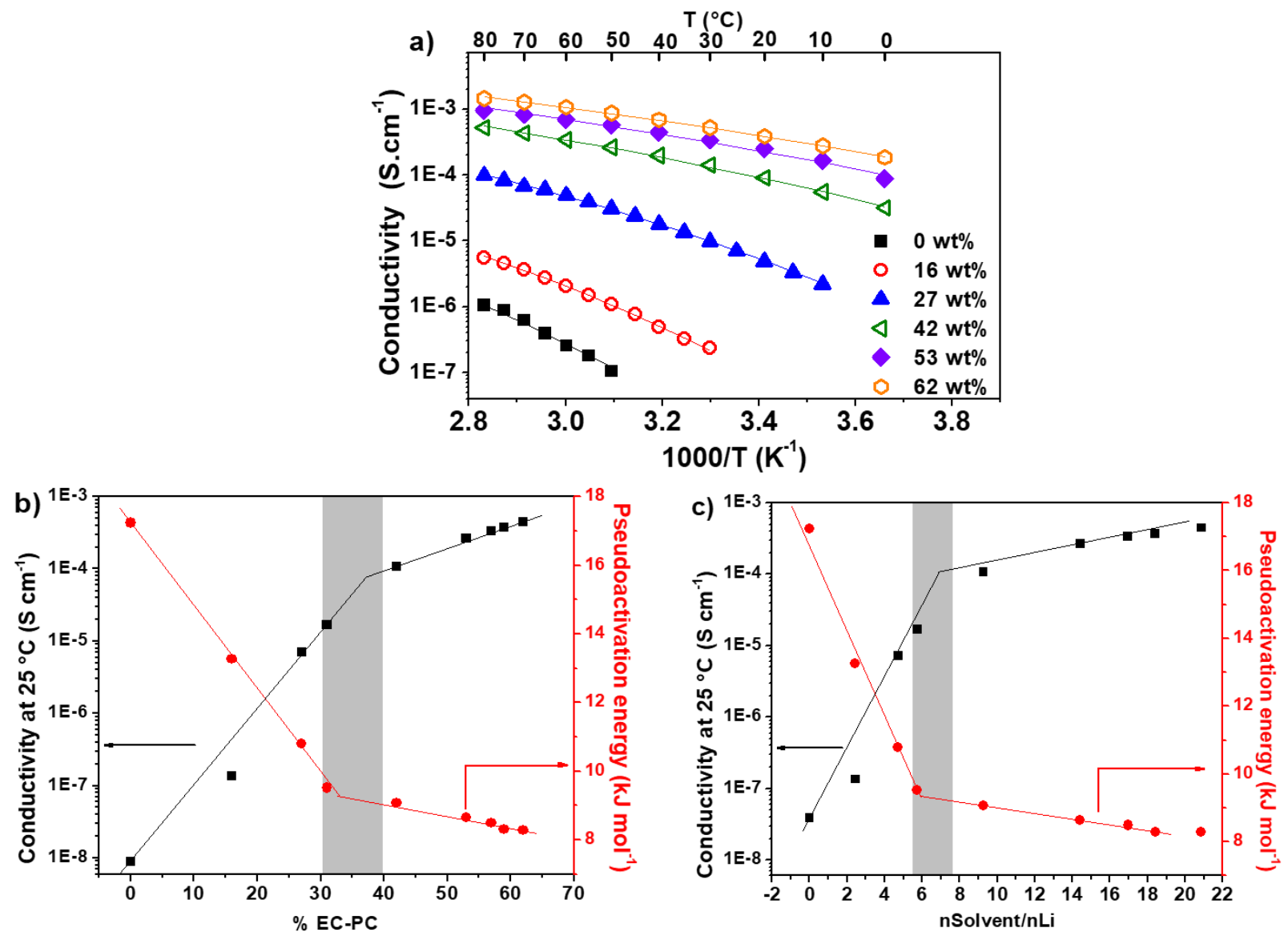

Fig. 2. a) Conductivity as a function of temperature of Li-PVDF-x membranes containing different solvent contents (x) with their VTF fitting (best fitting parameters listed in Table S1); b) Isothermal conductivity at $25^{\circ} \mathrm{C}$ and pseudoactivation energy calculated from VTF fit of conductivity data as a function of solvent content in wt $\%$; c) isothermal conductivity at 25 
${ }^{\circ} \mathrm{C}$ and pseudo-activation energy as a function of the number of moles of solvent ( $\left.\mathrm{n}_{\text {solvent }}\right) /$ number of moles of lithium $\left(\mathrm{n}_{\mathrm{Li}}\right)$ ratio.

An increase in solvent content induces a continuous rise in conductivity, which could be explained by: (i) an enhanced ion-pair dissociation, i.e., increasing number of free mobile charges, (ii) an increase of the molecular dynamics facilitating faster ion motions in agreement with the decrease of both the SIPE glass transition temperature, and (iii) a better percolation of the ionic domains $[23,74,75]$. The best ionic conductivity (e.g., Li-PVDF-60 doped with 60 wt $\%$ of solvent) reaches $5 \times 10^{-4} \mathrm{~S} \mathrm{~cm}^{-1}$ at $25{ }^{\circ} \mathrm{C}$ (Fig. 2b) [76]. Fig. 2b displays the evolution of the calculated conductivity at $25^{\circ} \mathrm{C}$ and the pseudo-activation energy thanks to VTF fits as a function of solvent uptake. It shows two distinct behaviours for low and high solvent concentrations with a threshold at about 35-45 wt\% (grey zone in Fig. 2b), corresponding to 6-8 molecules of solvent over one lithium cation (see Fig. 2c). In the low-EC/PC region below the threshold, an exponential increase in conductivity of almost 3 orders of magnitude (from $4 \times 10^{-8} \mathrm{~S} \mathrm{~cm}^{-1}$ to $2 \times 10^{-5} \mathrm{~S} \mathrm{~cm}^{-1}$ ) is observed. In parallel, the pseudo-activation energy decreases linearly (from 17 to $9 \mathrm{~kJ} \mathrm{~mol}^{-1}$ ), which matches an easiest ionic transport. Above the threshold, the isothermal conductivity continues to increase, while $E_{a}$ decreases but in a much slower manner.

These results are in good agreement with the DSC findings where, for a solvent content $<40$ $\mathrm{wt} \%$, the solvent strongly interacts with the ionic moieties of the polymer, thus significantly contributing to the ion pair dissociation and polymer dynamics. Moreover, for $\mathrm{x}>40 \mathrm{wt} \%$, the membranes contain rich solvent domains, which also leads to an enhanced Li-ion mobility, presumably related to a reduced local viscosity and a further improved connectivity.

The plasticized Li-PVDF-60 membrane exhibits an excellent single-ion conductivity, which is higher than that of membrane blends of PVDF and liquid electrolytes. For example, a conductivity of $c a \cdot 10^{-4} \mathrm{~S} \mathrm{~cm}^{-1}$ at room temperature was obtained for EC-PC doped PVDF containing $\mathrm{LiBF}_{4}$ [19] or $\mathrm{LiN}\left(\mathrm{SO}_{2} \mathrm{CFr}\right)_{2}$ [14] or EC plasticized $\mathrm{PVDF}-\mathrm{LiCF}_{3} \mathrm{SO}_{3}$ [74].

Further electrochemical characterizations were conducted on a Li-PVDF plasticized with 55 wt\% EC-PC, denoted Li-PVDF-55, that exhibited the best compromise between conductivity and mechanical behavior.

\subsection{Electrochemical stability}


Electrochemical stability of plasticized Li-PVDF membranes was evaluated from cyclic voltammetry at $80{ }^{\circ} \mathrm{C}$, and revealed an electrochemical stability window (ESW) spanning 4.3 V when employing stainless steel working electrode (WE), which is in agreement with the ESW of carbonate based electrolytes [77] (Fig. 3). Similar results were obtained from other groups when studying solvent doped salt-containing PVDF membranes, e.g., PVDF plasticized with $\mathrm{LiN}\left(\mathrm{SO}_{2} \mathrm{CF}_{3}\right)_{2}$ in PC [22] or $\mathrm{LiPF}_{6}$ in EC/DMC/DEC solvent [25]. Tiny peaks can be noted around $1 \mathrm{~V} v s . \mathrm{Li}^{+} / \mathrm{Li}$ which may be due to intercalation/de-intercalation in the oxide layers on the stainless steel WE [78]. Two peaks at $-0.5 \mathrm{~V}$ and $+0.54 \mathrm{~V} v s$. $\mathrm{Li}^{+} / \mathrm{Li}$, correspond to the reversible plating and stripping of lithium onto stainless steel working electrode $[79,80]$ with high current density. Coulombic efficiency of lithium plating/stripping process of this PVDF membrane was calculated as $83 \%$, which is rather high considering the known instability of carbonate based electrolytes on lithium electrode which generally present Coulombic efficiency lower than $80 \%$ [81].
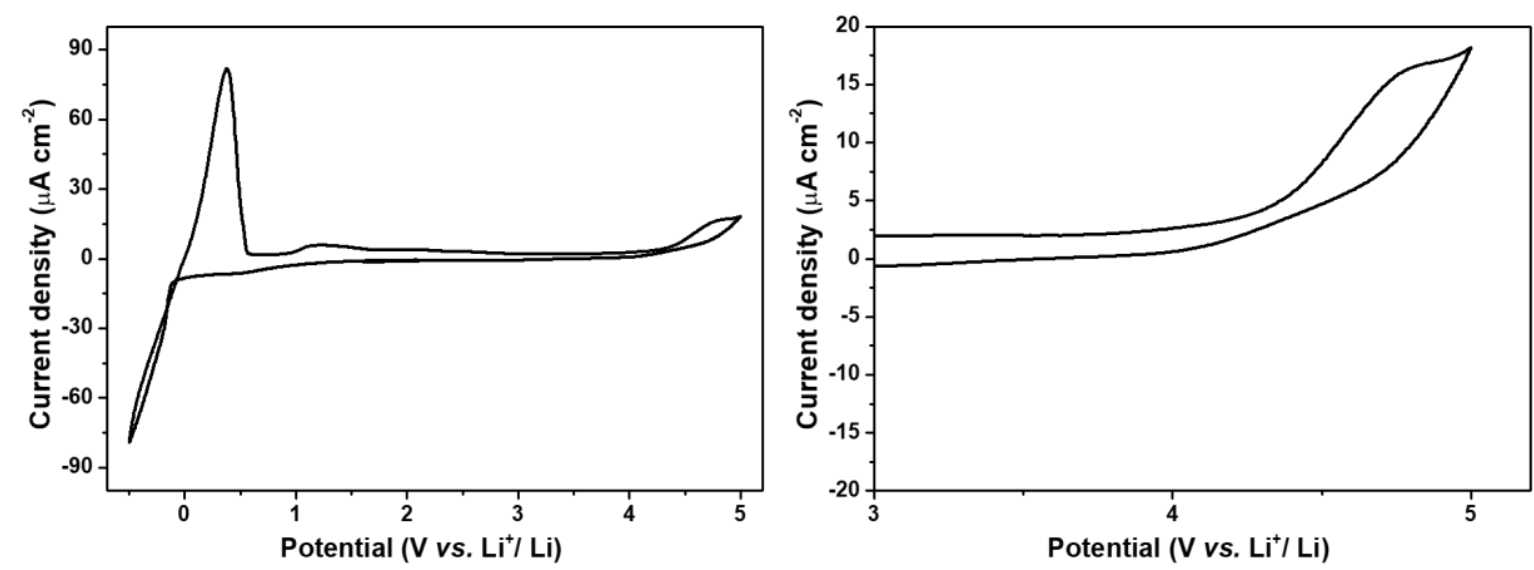

Fig. 3. Cyclic voltammetry of Li-PVDF-55 membrane using Li/stainless steel cell from -0.5 to $5 \mathrm{~V} v s . \mathrm{Li}^{+} / \mathrm{Li}$ at a slow sweep rate of $0.1 \mathrm{mV} \mathrm{s}^{-1}$. The figure on the right is the magnification of the current density versus 3-5 $\mathrm{V}$ range $v s . \mathrm{Li}^{+} / \mathrm{Li}$ zone.

\subsection{Evaluation of lithium plating/stripping efficiency}

Lithium stripping/plating cycling tests coupled with impedance spectroscopy was conducted at $60{ }^{\circ} \mathrm{C}$ on symmetric $\mathrm{Li} / \mathrm{Li}$ cells separated by the Li-PVDF-55 membrane (Fig. 4). The polarization of this cell is negligible at low applied current density of $0.01 \mathrm{~mA} \mathrm{~cm}^{-2}(2 \mathrm{mV})$ and it increases linearly with the stepwise applied current density up to $86 \mathrm{mV}$ at $0.5 \mathrm{~mA} \mathrm{~cm}{ }^{-2}$ (Fig. 4c), which shows an ohmic behavior, as expected for a single-ion electrolyte which presents high lithium plating/stripping kinetics. Indeed, the polarization is mostly due to the solid electrolyte interphase (SEI) on the lithium surface as shown in the Nyquist plot in Fig. 
4d. These values are comparable with a recent study on EC-doped single-ion multi-block copolymer [46]. Finally, a reversible decrease of the polarization when current density is decreased to $0.2 \mathrm{~mA} \mathrm{~cm}^{-2}$ suggests a very stable SEI between the polymer electrolyte and the lithium electrode. This is confirmed by the galvanostatic impedance spectroscopy analysis along plating/stripping cycling measurements, which show that the interface resistance only varied slightly (but not monotonously) with the different applied current densities. This slight variation can be explained by the reorganization of the lithium/electrolyte interface upon continuous lithium stripping and plating [25,46]. These results demonstrate the good compatibility of our SIPE with lithium metal.

Finally, Fig. 4b shows a zoom on characteristic cycles (herein obtained at $0.1,0.3$ and $0.5 \mathrm{~mA}$ $\mathrm{cm}^{-2}$, respectively). The polarization upon the application of current density is immediately achieved, which further confirms the single-ion conductivity of our SIPE [54,82].
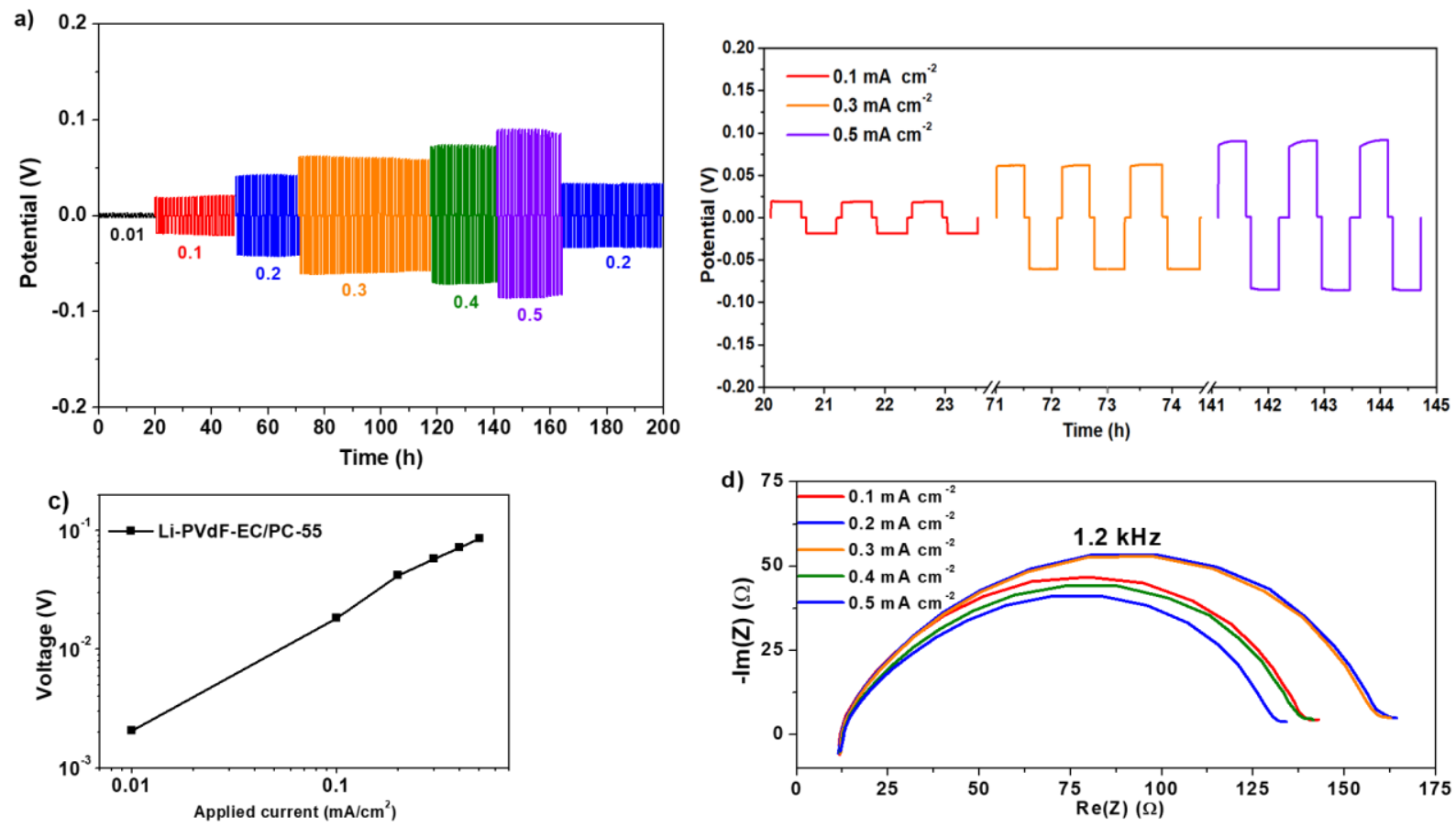

Fig. 4. Lithium plating/stripping cycling measurements obtained at $60{ }^{\circ} \mathrm{C}$ in a symmetric $\mathrm{Li} / \mathrm{Li}$ cell using Li-PVDF-55 membrane. (a) Effect of increasing current densities (0.01, 0.1, 0.3, $0.4,0.5 \mathrm{~mA} \mathrm{~cm}^{-2}$ ), followed by lowering the current density to $0.2 \mathrm{~mA} \mathrm{~cm}{ }^{-2}$. The duration of each lithium plating and striping step is $30 \mathrm{~min}$; (b) Magnification of characteristic plating/stripping cycles at $0.1,0.3$ and $0.5 \mathrm{~mA} . \mathrm{cm}^{-2}$; (c) Evolution of the polarization versus the applied current density; (d) Galvanostatic electrochemical impedance spectra of the Li/Li cell obtained for the different applied current densities (Nyquist plots). 


\subsection{Cycling performance of Li/NMC battery}

To further demonstrate the interest of this new SIPE, the cycling performance at $60{ }^{\circ} \mathrm{C}$ of an $\mathrm{Li} / \mathrm{NMC}$ battery in coin cell configuration has been tested. It is worth noting that the LiPVDF-55 was used as both electrolyte separator and binder in the composite electrode. The cut off voltage of the charge was $4.2 \mathrm{~V} v s . \mathrm{Li}^{+} / \mathrm{Li}$. The results are shown in Fig. 5.

The cycling is reversible (Fig. 5b), with $143 \mathrm{mAh} \mathrm{g}^{-1}$ at low C-rate of C/20 (D/20, D = discharge capacity), approaching theoretical capacity. After 20 cycles, the C-Rate $\mathrm{C}$ is increased to $\mathrm{C} / 10$ in charge and $\mathrm{D} / 5$ in discharge, which induces a drop of the capacity to 132 $\mathrm{mAh} \mathrm{g}^{-1}$ (Fig. 5a) followed by about thirty very stable cycles. After 55 cycles the discharge rate is increased to D/3 (Fig. 5a), which leads to a slow decrease in discharge capacity from 132 to $120 \mathrm{mAh} \mathrm{g}^{-1}$ over the next 40 cycles. This value then remains very stable for the next 100 cycles (Fig5B). The faradic efficiency is $98 \%$, and overall after 200 cycles the capacity retention is $80.16 \%$. It can be noted that these cycle conditions are quite harsh since the Crates are low and the temperature is high, which favors parasitic interfacial reactions, generally leading to a rapid decrease of the capacity in classical Li-ion technology. Therefore, these results show the promising potential of the SIPE designed on the basis of a PVDF skeleton instead of a PEO skeleton [15].
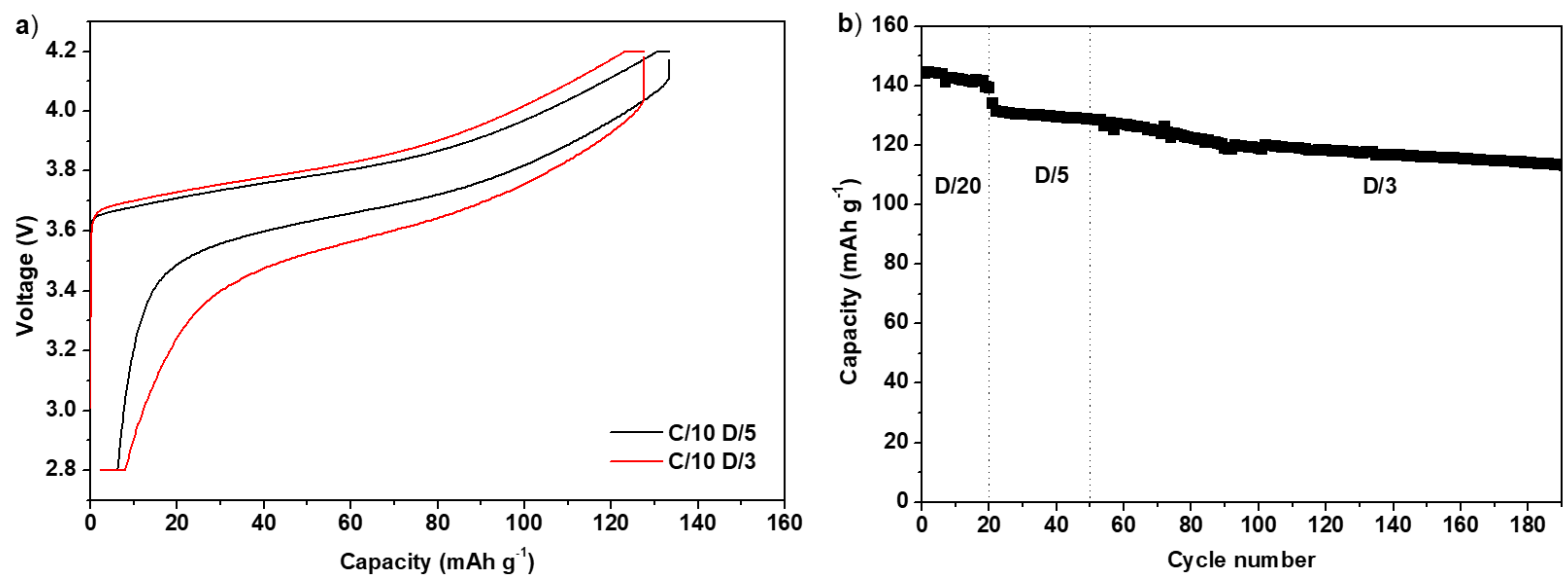

Fig. 5. Cycling performance of a NMC battery cell with Li-PVDF-55 as both electrolyte and cathode binder at $60{ }^{\circ} \mathrm{C}$ and various cycling rates: (a) Charge and discharge curves $\mathrm{C} / 10, \mathrm{D} / 5$ (cycle 20) and C/10 D/3 (cycle 55) and (b) Capacity versus cycle number.

\section{Conclusion}

A new lithium single-ion conducting PVDF-based copolymer was successfully synthesized by conventional and up-scalable radical copolymerization of VDF with a perfluorovinyl ether monomer bearing both sulfonimide and sulfonyl fluoride side-groups. The resulting copolymer had a molar mass of $128 \mathrm{~kg} \mathrm{~mol}^{-1}$ and contained $94 \mathrm{~mol} \%$ of VDF. The 
dry membrane was plasticized using a $50 / 50 \mathrm{v} / \mathrm{v}$ of EC and PC mixture to provide selfstanding solid state electrolyte membranes combining high single-ion conductivity of $5 \times 10^{-4} \mathrm{~S}$ $\mathrm{cm}^{-1}$ at $25{ }^{\circ} \mathrm{C}$ (with $60 \mathrm{wt} \% \mathrm{EC} / \mathrm{PC}$ ), an electrochemical window spanning $4.3 \mathrm{~V}$, an excellent reversibility of lithium plating/striping in symmetric $\mathrm{Li} / \mathrm{Li}$ cell, and very good capacity retention in high potential Li/NMC ASSB battery. This work paves the way for the design of new efficient SIPEs based on a PVDF backbone. Their promising performances open many perspectives for the development of solid-state batteries.

\section{Acknowledgements}

The authors thank Arkema (France) and Juhua (People's Republic of China) companies for kindly providing free samples of VDF and VEPFSIS, respectively, the Centre of Excellence of Multifunctional Architectured Materials "CEMAM" no. AN-10-LABX-44-01 for funding support, and Mr Vincent Martin from LEPMI for his help in SEC-MALLs and ICP-MS. The French Fluorine Network (GIS) is also acknowledged.

\section{References}

[1] S. Chu, Y. Cui, N. Liu, The path towards sustainable energy, Nat. Mater. 16 (2017) 1622. https://doi.org/10.1038/nmat4834.

[2] H. Gwon, J. Hong, H. Kim, D.H. Seo, S. Jeon, K. Kang, Recent progress on flexible lithium rechargeable batteries, Energy Environ. Sci. 7 (2014) 538-551. https://doi.org/10.1039/c3ee42927j.

[3] W. Xu, J. Wang, F. Ding, X. Chen, E. Nasybulin, Y. Zhang, J.-G. Zhang, Lithium metal anodes for rechargeable batteries, Energy Environ. Sci. 7 (2014) 513-537. https://doi.org/10.1039/C3EE40795K.

[4] H. Zhang, C. Li, M. Piszcz, E. Coya, T. Rojo, L.M. Rodriguez-Martinez, M. Armand, Z. Zhou, Single lithium-ion conducting solid polymer electrolytes: Advances and perspectives, Chem. Soc. Rev. 46 (2017) 797-815. https://doi.org/10.1039/c6cs00491a.

[5] Reading through breakthroughs, Nat. Energy. 2 (2017) 17126. https://doi.org/10.1038/nenergy.2017.126.

[6] P. Albertus, S. Babinec, S. Litzelman, A. Newman, Status and challenges in enabling the lithium metal electrode for high-energy and low-cost rechargeable batteries, Nat. Energy. 3 (2018) 16-21. https://doi.org/10.1038/s41560-017-0047-2. 
[7] M. Armand, Polymer solid electrolytes - an overview, Solid State Ionics. 9-10 (1983) 745-754. https://doi.org/10.1016/0167-2738(83)90083-8.

[8] F. Gray, M. Armand, Polymer Electrolytes, Handb. Batter. Mater. 16 (2007) 499-523. https://doi.org/10.1002/9783527611676.ch20.

[9] J.R. Nair, F. Colò, A. Kazzazi, M. Moreno, D. Bresser, R. Lin, F. Bella, G. Meligrana, S. Fantini, E. Simonetti, G.B. Appetecchi, S. Passerini, C. Gerbaldi, Room temperature ionic liquid (RTIL)-based electrolyte cocktails for safe, high working potential Li-based polymer batteries, J. Power Sources. $412 \quad$ (2019) 398-407. https://doi.org/10.1016/j.jpowsour.2018.11.061.

[10] Y. Zhang, J. Wang, J. Qiu, X. Jin, M.M. Umair, R. Lu, S. Zhang, B. Tang, Aggraphene/PEG composite phase change materials for enhancing solar-thermal energy conversion and storage capacity, Appl. Energy. 237 (2019) 83-90. https://doi.org/10.1016/j.apenergy.2018.12.075.

[11] G. Piana, F. Bella, F. Geobaldo, G. Meligrana, C. Gerbaldi, PEO/LAGP hybrid solid polymer electrolytes for ambient temperature lithium batteries by solvent-free, "one

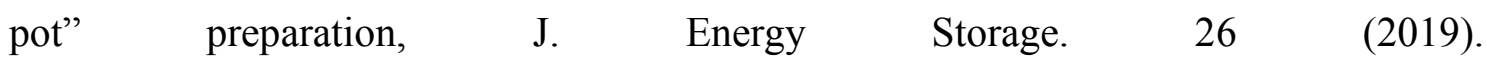
https://doi.org/10.1016/j.est.2019.100947.

[12] S. Wang, Q. Sun, W. Peng, Y. Ma, Y. Zhou, D. Song, H. Zhang, X. Shi, C. Li, L. Zhang, Ameliorating the interfacial issues of all-solid-state lithium metal batteries by constructing polymer/inorganic composite electrolyte, J. Energy Chem. 58 (2021) 8593. https://doi.org/10.1016/j.jechem.2020.09.033.

[13] Y. Chen, Y. Luo, H. Zhang, C. Qu, H. Zhang, X. Li, The Challenge of Lithium Metal Anodes for Practical Applications, Small Methods. 3 (2019) 1800551. https://doi.org/10.1002/smtd.201800551.

[14] C.M. Costa, E. Lizundia, S. Lanceros-Méndez, Polymers for advanced lithium-ion batteries: State of the art and future needs on polymers for the different battery components, Prog. Energy Combust. Sci. $79 \quad$ (2020) 100846. https://doi.org/10.1016/j.pecs.2020.100846.

[15] A. Lassagne, E. Beaudoin, A. Ferrand, T.N.T. Phan, P. Davidson, C. Iojoiu, R. Bouchet, New approach to design solid block copolymer electrolytes for $40{ }^{\circ} \mathrm{C}$ lithium metal battery operation, Electrochim. Acta. $238 \quad$ (2017) 21-29. 
https://doi.org/10.1016/j.electacta.2017.03.221.

[16] Z. Jiang, B. Carroll, K.M. Abraham, Studies of some poly(vinylidene fluoride) electrolytes, Electrochim. Acta. 42 (1997) 2667-2677. https://doi.org/10.1016/S00134686(97)00005-4.

[17] B. Ameduri, From vinylidene fluoride (VDF) to the applications of VDF-Containing polymers and copolymers: Recent developments and future trends, Chem. Rev. 109 (2009) 6632-6686. https://doi.org/10.1021/cr800187m.

[18] J.T. Goldbach, R. Amin-Sanayei, W. He, J. Henry, W. Kosar, A. Lefebvre, G. O’Brien, D. Vaessen, K. Wood, S. Zerafati, Chapter 6: Commercial Synthesis and Applications of Poly(Vinylidene Fluoride), in: B. Ameduri, H. Sawada (Eds.), Fluorinated Polym. Vol. 2 Appl., Royal Society of Chemistry, 2017: pp. 127-157. https://doi.org/10.1039/9781782629368-00127.

[19] A.L.S. Eh, X. Lu, P.S. Lee, Advances in Polymer Electrolytes for Electrochromic Applications, in: R.J. Mortimer, D.R. Rosseinsky, P.M.S. Monk (Eds.), Electrochromic Mater. Devices, Wiley Blackwell, 2015: pp. 289-310. https://doi.org/10.1002/9783527679850.ch10.

[20] W. Pu, X. He, L. Wang, C. Jiang, C. Wan, Preparation of PVDF-HFP microporous membrane for Li-ion batteries by phase inversion, J. Memb. Sci. 272 (2006) 11-14. https://doi.org/10.1016/j.memsci.2005.12.038.

[21] G. Vijayakumar, S.N. Karthick, A. Subramania, A New Class of P(VdF-HFP)- $\mathrm{CeO}_{2}$ $\mathrm{LiClO}_{4}$-Based Composite Microporous Membrane Electrolytes for Li-Ion Batteries , Int. J. Electrochem. 2011 (2011) 1-10. https://doi.org/10.4061/2011/926383.

[22] H.S. Choe, J. Giaccai, M. Alamgir, K.M. Abraham, Preparation and characterization of poly(vinyl sulfone)- and poly(vinylidene fluoride)-based electrolytes, Electrochim. Acta. 40 (1995) 2289-2293. https://doi.org/10.1016/0013-4686(95)00180-M.

[23] P. Periasamy, K. Tatsumi, M. Shikano, T. Fujieda, Y. Saito, T. Sakai, M. Mizuhata, A. Kajinami, S. Deki, Studies on PVdF-based gel polymer electrolytes, J. Power Sources. 88 (2000) 269-273. https://doi.org/10.1016/S0378-7753(99)00348-1.

[24] N. Muniyandi, N. Kalaiselvi, P. Periyasamy, R. Thirunakaran, B. Ramesh Babu, S. Gopukumar, T. Premkumar, N.G. Renganathan, M. Raghavan, Optimisation of PVdFbased polymer electrolytes, J. Power Sources. $96 \quad$ (2001) 14-19. 
https://doi.org/10.1016/S0378-7753(01)00562-6.

[25] J.R. Kim, S.W. Choi, S.M. Jo, W.S. Lee, B.C. Kim, Electrospun PVdF-based fibrous polymer electrolytes for lithium ion polymer batteries, Electrochim. Acta. 50 (2004) 69-75. https://doi.org/10.1016/j.electacta.2004.07.014.

[26] A.S. Gozdz, J.-M. Tarascon, Schmutz, Rechargeable lithium interaction battery with flexible electrolyte. $\quad 1994$. https://patentimages.storage.googleapis.com/5a/09/6b/535ed98fa4a243/US5296318.pdf (accessed April 3, 2019).

[27] K.M. Kim, N.-G. Park, K.S. Ryu, S.H. Chang, Characteristics of PVdF-HFP/TiO composite membrane electrolytes prepared by phase inversion and conventional casting methods, Electrochim. Acta. $51 \quad$ (2006) 5636-5644. https://doi.org/10.1016/j.electacta.2006.02.038.

[28] R. Miao, B. Liu, Z. Zhu, Y. Liu, J. Li, X. Wang, Q. Li, PVDF-HFP-based porous polymer electrolyte membranes for lithium-ion batteries, J. Power Sources. 184 (2008) 420-426. https://doi.org/10.1016/j.jpowsour.2008.03.045.

[29] F. Croce, M.L. Focarete, J. Hassoun, I. Meschini, B. Scrosati, A safe, high-rate and high-energy polymer lithium-ion battery based on gelled membranes prepared by electrospinning, Energy Environ. Sci. $4 \quad$ (2011) 921-927. https://doi.org/10.1039/c0ee00348d.

[30] Z.-Y. Lian, C.-C. Yang, J.-Y. Shih, W.-H. Chen, S.J. Lin, Preparation and application of PVDF-HFP composite polymer electrolytes in $\mathrm{LiNi}_{0.5} \mathrm{Co}_{0.2} \mathrm{Mn}_{0.3} \mathrm{O}_{2}$ lithium-polymer batteries, Electrochim. Acta. $134 \quad$ (2014) 258-265. https://doi.org/10.1016/j.electacta.2014.04.100.

[31] M. Wehbi, G. Dolphijn, J. Brassinne, J.F. Gohy, B. Ameduri, Synthesis of Vinylidene Fluoride-Based Copolymers Bearing Perfluorinated Ether Pendant Groups and Their Application in Gel Polymer Electrolytes, Macromolecules. 52 (2019) 3056-3065. https://doi.org/10.1021/acs.macromol.9b00355.

[32] Y. Wang, J. Travas-Sejdic, R. Steiner, Polymer gel electrolyte supported with microporous polyolefin membranes for lithium ion polymer battery, Solid State Ionics. 148 (2002) 443-449. https://doi.org/10.1016/S0167-2738(02)00085-1.

[33] S. Rajendran, O. Mahendran, R. Kannan, Lithium ion conduction in plasticized PMMA- 
PVdF polymer blend electrolytes, Mater. Chem. Phys. 74 (2002) 52-57. https://doi.org/10.1016/S0254-0584(01)00400-X.

[34] L. Sannier, R. Bouchet, L. Santinacci, S. Grugeon, J.-M. Tarascon, Lithium Metal Batteries Operating at Room Temperature Based on Different PEO-PVdF Separator Configurations, J. Electrochem. Soc. $151 \quad$ (2004) A873. https://doi.org/10.1149/1.1710516.

[35] L. Sannier, R. Bouchet, S. Grugeon, E. Naudin, E. Vidal, J.-M. Tarascon, Room temperature lithium metal batteries based on a new Gel Polymer Electrolyte membrane, J. Power Sources. 144 (2005) 231-237. https://doi.org/10.1016/j.jpowsour.2004.11.064.

[36] Q. Cao, X. Wang, L. Zhou, X. Tang, N. Wu, B. Jing, Study of a novel porous gel polymer electrolyte based on thermoplastic polyurethane/poly(vinylidene fluoride-cohexafluoropropylene) by electrospinning technique, J. Power Sources. 263 (2014) 118124. https://doi.org/10.1016/j.jpowsour.2014.03.140.

[37] S. Peng, Q. Cao, J. Yang, X. Zou, B. Jing, W. Dai, A novel electrospun poly(vinylidene fluoride)/thermoplastic polyurethane/poly(vinylidene fluoride)-g-(maleic anhydride) porous fibrous polymer electrolyte for lithium-ion batteries, Solid State Ionics. 282 (2015) 49-53. https://doi.org/10.1016/j.ssi.2015.09.018.

[38] J.-Y. Sanchez, F. Alloin, J. Saunier, PVdF-based polymers for lithium batteries, in: T. Nakajima, H. Groult (Eds.), Fluorinated Mater. Energy Convers., Elsevier Ltd, 2005: pp. 305-333. https://doi.org/10.1016/B978-008044472-7/50042-4.

[39] C.M. Costa, M.M. Silva, S. Lanceros-Méndez, Battery separators based on vinylidene fluoride (VDF) polymers and copolymers for lithium ion battery applications, RSC Adv. 3 (2013) 11404-11417. https://doi.org/10.1039/c3ra40732b.

[40] C. Capiglia, Y. Saito, H. Yamamoto, H. Kageyama, P. Mustarelli, Transport properties and microstructure of gel polymer electrolytes, Electrochim. Acta. 45 (2000) 13411345. https://doi.org/10.1016/S0013-4686(99)00342-4.

[41] J.-N.N. Chazalviel, Electrochemical aspects of the generation of ramified metallic electrodeposits, Phys. Rev. A. $42 \quad$ (1990) 7355-7367. https://doi.org/10.1103/PhysRevA.42.7355.

[42] M. Rosso, T. Gobron, C. Brissot, J.N. Chazalviel, S. Lascaud, Onset of dendritic growth in lithium/polymer cells, J. Power Sources. 97-98 (2001) 804-806. 
https://doi.org/10.1016/S0378-7753(01)00734-0.

[43] R. Bouchet, S. Maria, R. Meziane, A. Aboulaich, L. Lienafa, J.P. Bonnet, T.N.T. Phan, D. Bertin, D. Gigmes, D. Devaux, R. Denoyel, M. Armand, Single-ion BAB triblock copolymers as highly efficient electrolytes for lithium-metal batteries, Nat. Mater. 12 (2013) 452-457. https://doi.org/10.1038/nmat3602.

[44] D. Devaux, L. Liénafa, E. Beaudoin, S. Maria, T.N.T. Phan, D. Gigmes, E. Giroud, P. Davidson, R. Bouchet, Comparison of single-ion-conductor block-copolymer electrolytes with Polystyrene-TFSI and Polymethacrylate-TFSI structural blocks, Electrochim. Acta. 269 (2018) 250-261. https://doi.org/10.1016/j.electacta.2018.02.142.

[45] L. Porcarelli, A.S. Shaplov, F. Bella, J.R. Nair, D. Mecerreyes, C. Gerbaldi, Single-Ion Conducting Polymer Electrolytes for Lithium Metal Polymer Batteries that Operate at Ambient Temperature, ACS Energy Lett. 1 (2016) 678-682. https://doi.org/10.1021/acsenergylett.6b00216.

[46] H.D. Nguyen, G.T. Kim, J. Shi, E. Paillard, P. Judeinstein, S. Lyonnard, D. Bresser, C. Iojoiu, Nanostructured multi-block copolymer single-ion conductors for safer highperformance lithium batteries, Energy Environ. Sci. 11 (2018) 3298-3309. https://doi.org/10.1039/c8ee02093k.

[47] K. Jeong, S. Park, S.Y. Lee, Revisiting polymeric single lithium-ion conductors as an organic route for all-solid-state lithium ion and metal batteries, J. Mater. Chem. A. 7 (2019) 1917-1935. https://doi.org/10.1039/c8ta09056d.

[48] Y. Ding, X. Shen, J. Zeng, X. Wang, L. Peng, P. Zhang, J. Zhao, Pre-irradiation grafted single lithium-ion conducting polymer electrolyte based on poly(vinylidene fluoride), Solid State Ionics. 323 (2018) 16-24. https://doi.org/10.1016/j.ssi.2018.05.009.

[49] Z. Ma, Y. Yin, L. Li, Z. Wang, S. Li, S. Tian, Lithium sulfonate-grafted poly(vinylidenefluoride-hexafluoro propylene) ionomer as binder for lithium-ion batteries, RSC Adv. 8 (2018) 20025-20031. https://doi.org/10.1039/c8ra02122h.

[50] M. Colpaert, M. Zatoń, G. Lopez, D.J. Jones, B. Améduri, Revisiting the radical copolymerization of vinylidene fluoride with perfluoro-3,6-dioxa-4-methyl-7-octene sulfonyl fluoride for proton conducting membranes, Int. J. Hydrogen Energy. 43 (2018) 16986-16997. https://doi.org/10.1016/j.ijhydene.2018.03.153.

[51] O. Danyliv, C. Iojoiu, S. Lyonnard, N. Sergent, E. Planes, J.Y. Sanchez, Highly Phase 
Separated Aromatic Ionomers Bearing Perfluorosulfonic Acids by Bottom-up Synthesis: Effect of Cation on Membrane Morphology and Functional Properties, Macromolecules. 49 (2016) 4164-4177. https://doi.org/10.1021/acs.macromol.6b00629.

[52] O. Danyliv, C. Iojoiu, V. Barbier, V. Martin, J.Y. Sanchez, Aromatic ionic monomer bearing perfluorosulfonate moiety and its polycondensation toward high performance superacid ionomers, J. Fluor. Chem. $189 \quad$ (2016) 43-50. https://doi.org/10.1016/j.jfluchem.2016.07.017.

[53] M. Watanabe, S. Nagano, K. Sanui, N. Ogata, Estimation of Li+ transport number in polymer electrolytes by the combination of complex impedance and potentiostatic polarization measurements, Solid State Ionics. 28-30 (1988) 911-917. https://doi.org/10.1016/0167-2738(88)90303-7.

[54] P.G. Bruce, C.A. Vincent, Transport in associated polymer electrolytes, Solid State Ionics. 40-41 (1990) 607-611. https://doi.org/10.1016/0167-2738(90)90079-7.

[55] K. Nakagawa, Y. Ishida, Estimation of amorphous specific volume of poly(vinylidene fluoride) as a function of temperature, Kolloid-Zeitschrift Zeitschrift Für Polym. 251 (1973) 103-107. https://doi.org/10.1007/BF01498933.

[56] K. Nakagawa, Y. Ishida, Annealing effects in poly(vinylidene fluoride) as revealed by specific volume measurements, differential scanning calorimetry, and electron microscopy, J. Polym. Sci. Part B Polym. Phys. 11 (1973) 2153-2171. https://doi.org/10.1002/pol.1973.180111107.

[57] H. Vogel, Das Temperaturabhangigkeitsgesetz der viskositat von der Temperatur bei unterkuhlten Flussigkeiten, Phys Z. 22 (1926) 645-646. https://ci.nii.ac.jp/naid/10004192038 (accessed September 21, 2020).

[58] G. Tammann, W. Hesse, Die Abhängigkeit der Viscosität von der Temperatur bie unterkühlten Flüssigkeiten, Zeitschrift Für Anorg. Und Allg. Chemie. 156 (1926) 245257. https://doi.org/10.1002/zaac.19261560121.

[59] G.S. Fulcher, Analysis of recent measurements of the viscosity of glasses, J. Am. Ceram. Soc. 8 (1925) 339-355. https://doi.org/10.1111/j.1151-2916.1925.tb16731.x.

[60] R. Jung, M. Metzger, F. Maglia, C. Stinner, H.A. Gasteiger, Chemical versus Electrochemical Electrolyte Oxidation on NMC111, NMC622, NMC811, LNMO, and Conductive Carbon, J. Phys. Chem. Lett. $8 \quad$ (2017) 44. 
https://doi.org/10.1021/acs.jpclett.7b01927.

[61] T.R. Venkatesan, R. Gerhard, Origin of the mid-temperature transition in vinylidenefluoride-based ferro-, pyro- And piezoelectric homo-, co- And ter-polymers, Mater. Res. Express. 7 (2020). https://doi.org/10.1088/2053-1591/ab842c.

[62] D. Glennon, P.A. Cox, R.T. Nevell, T.G. Nevell, J.R. Smith, J. Tsibouklis, R.J. Ewen, Molecular organization in structural PVDF, J. Mater. Sci. 33 (1998) 3511-3517. https://doi.org/10.1023/A:1004630623660.

[63] O. Petrov, I. Furó, Curvature-dependent metastability of the solid phase and the freezing-melting hysteresis in pores, Phys. Rev. E - Stat. Nonlinear, Soft Matter Phys. 73 (2006). https://doi.org/10.1103/PhysRevE.73.011608.

[64] A.M. Stephan, Review on gel polymer electrolytes for lithium batteries, Eur. Polym. J. 42 (2006) 21-42. https://doi.org/10.1016/j.eurpolymj.2005.09.017.

[65] J.M. Tarascon, D. Guyomard, New electrolyte compositions stable over the 0 to $5 \mathrm{~V}$ voltage range and compatible with the Li1+xMn2O4/carbon Li-ion cells, Solid State Ionics. 69 (1994) 293-305. https://doi.org/10.1016/0167-2738(94)90418-9.

[66] J.M. Tarascon, A.S. Gozdz, C. Schmutz, F. Shokoohi, P.C. Warren, Performance of Bellcore's plastic rechargeable Li-ion batteries, Solid State Ionics. 86-88 (1996) 49-54. https://doi.org/10.1016/0167-2738(96)00330-X.

[67] J. Saunier, F. Alloin, J.Y. Sanchez, B. Barrière, Plasticized microporous poly(vinylidene fluoride) separators for lithium-ion batteries. I. Swelling behavior of dense membranes with respect to a liquid electrolyte-Characterization of the swelling equilibrium, J. Polym. Sci. Part B Polym. Phys. 42 (2004) 532-543. https://doi.org/10.1002/polb.10730.

[68] L.Y. Tian, X. Bin Huang, X.Z. Tang, Single-ionic gel polymer electrolyte based on polyvinylidene fluoride and fluorine-containing ionomer, Eur. Polym. J. 40 (2004) 735742. https://doi.org/10.1016/j.eurpolymj.2003.12.006.

[69] R.P. Sheldon, P.R. Blakey, Liquid-induced crystallization in polymers, Nature. 195 (1962) 172-173. https://doi.org/10.1038/195172a0.

[70] S. Andjelic, R. Scogna, S. Sa, A. Andjelic',, R.C. Scogna, Polymer crystallization rate challenges: The art of chemistry and processing, J. Appl. Polym. Sci. 132 (2015) 42066-42066. https://doi.org/10.1002/app.42066. 
[71] V. Pokorný, V. Štejfa, M. Fulem, C. Červinka, K. Růžička, Vapor Pressures and Thermophysical Properties of Ethylene Carbonate, Propylene Carbonate, $\gamma$ Valerolactone, and $\gamma$-Butyrolactone, J. Chem. Eng. Data. 62 (2017) 4174-4186. https://doi.org/10.1021/acs.jced.7b00578.

[72] Y. Zhang, J. Wang, C. Tan, Y. He, Y. Chen, S. Huo, D. Zeng, C. Li, H. Cheng, Fireretardant sp3 boron-based single ion conducting polymer electrolyte for safe, high efficiency and dendrite-free Li-metal batteries, J. Memb. Sci. 620 (2021) 118921. https://doi.org/10.1016/j.memsci.2020.118921.

[73] Y. He, J. Wang, Y. Zhang, S. Huo, D. Zeng, Y. Lu, Z. Liu, D. Wang, H. Cheng, Effectively suppressing lithium dendrite growth: Via an es-LiSPCE single-ion conducting nano fiber membrane, J. Mater. Chem. A. 8 (2020) 2518-2528. https://doi.org/10.1039/c9ta12783f.

[74] N.S. Mohamed, A.K. Arof, Investigation of electrical and electrochemical properties of PVDF-based polymer electrolytes, J. Power Sources. 132 (2004) 229-234. https://doi.org/10.1016/j.jpowsour.2003.12.031.

[75] J.B. Goodenough, K.S. Park, The Li-ion rechargeable battery: A perspective, J. Am. Chem. Soc. 135 (2013) 1167-1176. https://doi.org/10.1021/ja3091438.

[76] Y. Yamada, Y. Takazawa, K. Miyazaki, T. Abe, Electrochemical lithium intercalation into graphite in dimethyl sulfoxide-based electrolytes: Effect of solvation structure of lithium ion, J. Phys. Chem. C. $114 \quad$ (2010) 11680-11685. https://doi.org/10.1021/jp1037427.

[77] K. Xu, Electrolytes and interphases in Li-ion batteries and beyond, Chem. Rev. 114 (2014) 11503-11618. https://doi.org/10.1021/cr500003w.

[78] M. Armand, Polymer solid electrolytes - an overview, Solid State Ionics. 9-10 (1983) 745-754. https://doi.org/10.1016/0167-2738(83)90083-8.

[79] S. Choudhury, R. Mangal, A. Agrawal, L.A. Archer, A highly reversible roomtemperature lithium metal battery based on crosslinked hairy nanoparticles, Nat. Commun. 6 (2015) 1-9. https://doi.org/10.1038/ncomms10101.

[80] X. Wang, Z. Liu, C. Zhang, Q. Kong, J. Yao, P. Han, W. Jiang, H. Xu, G. Cui, Exploring polymeric lithium tartaric acid borate for thermally resistant polymer electrolyte of lithium batteries, Electrochim. Acta. 92 (2013) 132-138. 
https://doi.org/10.1016/j.electacta.2013.01.026.

[81] Y. Zhang, X. Liu, M.H. Engelhard, X. Chen, J.J.-G. Zhang, T.A. Blake, B.R. Johnson, J.J.-G. Zhang, W. Xu, F. Ding, J. V. Crum, Effects of Carbonate Solvents and Lithium Salts on Morphology and Coulombic Efficiency of Lithium Electrode, J. Electrochem. Soc. 160 (2013) A1894-A1901. https://doi.org/10.1149/2.100310jes.

[82] S.-W. Ryu, A.M. Mayes, J.A. Gonzalez-Leon, P.E. Trapa, D.R. Sadoway, S.C. Olugebefola, Effect of Counter Ion Placement on Conductivity in Single-Ion Conducting Block Copolymer Electrolytes, J. Electrochem. Soc. 152 (2005) A158A163. https://doi.org/10.1149/1.1828244. 